ПРОФЕСІЙНА ІНШОМОВНА ПІДГОТОВКА В ПРОЦЕСІ МІЖКУЛЬТУРНОї ІНТЕГРАШІЇ

\author{
Отримано: 9 вересня 2019 року \\ Прорецензовано: 16 вересня 2019 року \\ Прийнято до друку: 23 вересня 2019 року \\ e-mail: lisikeng@gmail.com \\ majalvov@gmail.com
}

DOI: $10.25264 / 2519-2558-2019-7(75)-148-151$

\author{
Afanasieva L. V., Smyrnova M. L. The role of a foreign language in the process of forming a \\ politically correct worldview among technical university students. Наукові записки Націо- \\ нального університету «Острозька академія»: серія «Філологія». Острог: Вид-во \\ НаУОА, 2019. Вип. 7(75), жовтень. С. 148-151.
}

УДК: $81^{\prime} 243: 378$

Larysa Afanasieva,

Instructor of the foreign languages department,

Dnipro National University of Railway Transport named after academician $V$. Lazarian

Maya Smyrnova,

Instructor of the foreign languages department,

Dnipro National University of Railway Transport named after academician $V$. Lazarian

\title{
THE ROLE OF A FOREIGN LANGUAGE IN THE PROCESS OF FORMING A POLITICALLY CORRECT WORLDVIEW AMONG TECHNICAL UNIVERSITY STUDENTS
}

The article, based on the analysis of the views of various linguistic scientists, shows the strengths of the foreign language, one of the oldest disciplines taught as an effective tool for the formation of a multicultural outlook among non-native speakers. Particular attention is paid to the importance of a foreign language as a compulsory component of a common culture, as well as an educational program of higher education. Polyculture is not laid on the genetic level. It is socially deterministic and should be formed in the educational process, and the ideas of linguocultural education by means of foreign languages should be implemented in the textbooks that are part of the educational and methodological complexes. In this regard, the design of courses, the development and implementation of native textbooks and teaching aids of the new generation is for students of non-English high schools considered as an indispensable condition for optimizing the learning process of a foreign language, which allows to effectively formulate a foreign-language multicultural outlook. An article may be of interest to high school teachers.

Key words: polycultural outlook, foreign language, formation, speech, effective tool, nonlinguistic students, teaching and educational process, optimization of the learning process, polycultural education, integrative approach.

\author{
Афанас'єва Лариса Вячеславівна, \\ викладач кафедри іноземних мов, \\ Дніпровський національний університет залізничного транспорту ім. академіка В. Лазаряна \\ Смирнова Майя Львівна, \\ викладач кафедри іноземних мов, \\ Дніпровський національний університет залізничного транспорту ім. академіка В. Лазаряна
}

\section{РОЛЬ ІНОЗЕМНОЇ МОВИ В ПРОЦЕСІ ФОРМУВАННЯ ПОЛІКУЛЬТУРНОГО СВІТОГЛЯДУ СЕРЕД СТУДЕНТІВ ТЕХНІЧНОГО УНІВЕРСИТЕТУ}

У статті на основі аналізу думок різних вчених-лінгвістів показані сильні сторони іноземної мови, однієї з найдавніших дисциплін, що викладаються, як ефективний інструмент формування полікультурного світогляду у студентів немовних спеціальностей. Особлива увага приділяється важливості іноземної мови як обов язкової складової загальної культури, так $і$ освітньої програми вищої школи. Полікультурність не закладаються на генетичному рівні. Вона соціально детермінована і повинна формуватися в навчально-виховному прочесі, $і$ ідеї лінгвокультурологічного освіти засобами іноземних мов повинні втілюватися в навчальних посібниках, які є частиною навчально-методичних комплексів. У зв'язку з цим, проектування курсів, розробка і впровадження вітчизняних підручників і навчальних посібників нового покоління саме для студентів немовних вузів розглядаються як неодмінна умова оптимізаиї процесу навчання іноземної мови, щчо дозволяє ефективно формувати іншомовне полікультурне світогляд. Стаття може представляти інтерес для преподавателей вищої школи.

Ключові слова: полікультурний світогляд, іноземна мова, формування, мова, ефективний інструмент, нелінгвістичні студенти, навчально-виховний процес, оптимізачія навчального процесу, полікультурна освіта, інтегративний підхід.

The modern communicative space of Ukraine today is characterized by modernization and striving for global information processes, where education plays a leading role in the modernization process. It is education that is the most important stage in the development of a multicultural language personality, which forms the basic values and life principles. Our state is a member of the 
world community, which sets a new goal for the Ukrainian education system - the formation of a multicultural language personality that can identify itself not only as a representative of its national culture, but also as a citizen of the world, who perceives itself as the subject of a dialogue of cultures and is aware of its role, significance, responsibility in global human processes.

Multicultural education in Ukraine should be one of the main directions in the education system, which creates conditions for preparing for intercultural communication, for ensuring social and academic mobility of young people, for preparing a versatile specialist with a high level of culture, is an organic part of language education in general, the fundamental concept of which is the linguistic personality. Under the term linguistic personality Yu.N. Karaulov understands "the totality of abilities and characteristics of a person, causing him to create speech works (texts), differing in the degree of structural and linguistic complexity, depth and accuracy of reflection of reality, defined by language purposefulness" [7, p. 3]. Each linguistic personality is formed on the basis of the appropriation by the concrete person of all the linguistic wealth created by the predecessors. The language of a specific personality consists to a greater degree of a common language and to a lesser degree - of individual linguistic features [10, pp. 132-134]. The general principles of activity of educational institutions for the development of a system of multicultural education in Ukraine are:

- openness of the national education system built on the dialogue of cultures;

- consideration of Ukraine-specific processes of inter-and intra-ethnic integration, ethno-cultural characteristics of each nation and ethnic group;

- fostering respect and interest in national values and peculiarities of Ukraine, language, way of life, traditions, faith, national culture;

- developing students' ability to adapt to a multicultural and multi-ethnic environment.

The tasks of multicultural education include:

- formation of ideas about culture and cultural diversity;

- familiarization with the cultural values of the peoples living in Ukraine, the formation of positive value orientations to the Ukrainian culture;

- formation of a positive attitude towards cultural differences, overcoming negative ethnosocial stereotypes;

- development of skills and abilities of productive interaction with carriers of different cultures;

- the formation of a culture of international communication [8].

The content of the multicultural educational space is distinguished by its multifunctionality, which meets the following criteria: reflected in the educational process of humanistic ideas, ideas of freedom and non-violence; the disclosure of common elements of traditions in the cultures of Kazakhstan's peoples, allowing them to live in peace, harmony, tolerance and harmony; the introduction of students to world culture, the disclosure of the process of globalization, the interdependence of countries and peoples in modern conditions; humanism, which expresses unconditional faith in the good beginnings inherent in human nature; democracy based on signs of equal rights and obligations of citizens, granting freedom of life in the family, school, and social environment; ethnotolerance, tolerance of a different kind of views, mores, habits, to the peculiarities of different nations, nations, religions; competence, i.e. the need to form the special abilities of the participants in the educational process in possession of knowledge, education of the intellectual personality, capable of solving problems of a creative nature in a multicultural society; basic development of the content of polycultural education, which should be the value-cultural, personality-oriented approaches.

A polycultural personality is understood as "an individual with a developed linguistic consciousness" [6, p. 20]. The basis of the formation of a multicultural personality is multilingualism. Multilingual education is a process of teaching, educating and developing an individual as a multilingual personality based on the simultaneous mastering of several languages, capable of carrying out communicative and activity operations in three languages in all situations striving for self-development and self-improvement.

According to modern European linguistic progressive trends, a multilingual personality is an active carrier of several languages, representing: the personality of a speech - a complex of psychophysiological properties that allow an individual to carry out speech activity simultaneously in several languages; communicative personality - a set of abilities to verbal behavior and the use of several languages as a means of communication with representatives of different linguistic societies; the vocabulary personality is a set of ideological attitudes, value orientations, behavioral experience, integrated in the lexical system of several languages [13, p. 93]

Multilingual education based on parallel teaching of three or more languages (Ukrainian - Russian - English) gives the carrier of national values access to the dialogue of worldviews and cultures. Thus, multicultural and multilingual education is necessary for the formation of a competitive specialist capable of active and effective life in a multiethnic and multicultural environment with a developed understanding and respect for other cultures, the ability to live in peace and harmony [15, p. 11], [16, p. 24]. In the normative documents of Ukraine, a strategy has been defined for the education of a multicultural person who speaks at least three languages and respects the culture and traditions of the peoples of the world. Knowledge of the native, state, Russian and foreign languages broadens the horizons of the future specialist, contributes to his multifaceted development, contributes to the formation of the installation on tolerance and volume vision of the world [11, p. 33].

In general, in the process of training in educational institutions, a moral, highly contextual multilingual personality should be formed, owning and possessing an arsenal of language tools, linguistic flair, constructive intelligence, positive communication, social responsibility and professional skills. Polycultural linguistic personality as the subject of one of the humanities disciplines linguistic personality - is a generalized image of the carrier of cultural-linguistic and communicative-activity values, knowledge, attitudes and behavioral responses. Thus, it should be concluded that in the educational space it is necessary to provide a single basic level of general education, to focus students on the formation of a professional culture, should form the information culture of the student with the introduction to the new educational environment, aimed at the development of multifunctional educational competence of a multicultural language personality with a certain set general professional, intercultural, communicative and personal qualities that let alone in the future to solve various problems of social professional life.

In terms of technological innovation and the "boom of language industry", modern higher education is faced with the task of forming a fully harmonious personality. The concept of human culture is closely connected with it, so modern students should acquire in the learning process systematic knowledge in the aggregate, laying the foundations of a common culture, which scientists call the scientific picture of the world. To this end, it is necessary to combine the efforts of all the disciplines studied, to more boldly 
develop synthetic approaches in the content of education, to link the individual components of a culture with each other. In this lies the task of private methods in order to give a decent place to each discipline, not isolating it from the others, but in the general interaction and influence on the formation of the general culture of the individual [3, p. 71].

Multiculturalism is laid not at the genetic level. She is socially determined and should be brought up [5].

An analysis of recent research and publications, in which aspects of this problem were considered points to its complexity and versatility. Various problems of multicultural education were studied by J. Banks, O. A. Shaymardinova, L. V. Brusova, Yu. S. Davydov, G. D. Dmitriev, M. N. Kuzminy, N. M. Lebedeva, V. V. Makaev, V. K. Shapovalov, etc. The research emphasizes the idea that the content of multicultural education is distinguished by a high degree of interdisciplinarity.

The objectives of the study can be formulated as a problem of scientific understanding. Polycultural education, including cultural, ethno-historical knowledge, implies the formation of future specialists' understanding of the importance of cultural pluralism, the ability to organize the pedagogical process as a dialogue of different cultures and a dialogue of carriers of different cultures in time and space. This approach allows us to consider the problems of multicultural education, including and as a unity of natural science and humanitarian knowledge, of natural science and humanitarian culture in general [17, p. 7].

One of the oldest disciplines taught is an important component of the general culture and one of the best ways to form a multicultural worldview is speech, language, and therefore languages should be studied in inseparable unity with the world and culture of the peoples speaking these languages. The growing interest in the phenomenon of culture, the interaction and interconnection of the problem of "language and culture" are reflected in the ideas of cultural linguistics, in the scientific discipline of the synthesizing type, characterized by a holistic systemic consideration of "language and culture" as an aggregate of units (linguistic culture). These include the names of objects, concepts, concepts that are not found or occur in another variant among the members of the Russian, national lingvovul of the tourological community [14, p. 38].

The modern development of linguistic culturology has put forward the study of linguistic and sociocultural processes in the course of the historical evolution of the ethnic group among the priority tasks, and the ideas of linguistic and culturological education by means of foreign languages are beginning to be embodied in the teaching and methodical complexes in the higher school for students of non-linguistic special stey. Such complexes can be used instead of official textbooks in accordance with the concept of modular training, successfully used in European colleges and the corresponding general trend of an integrative approach to learning a language based on the interrelated formation of skills in all types of speech activity: listening, speaking, reading, writing. In the domestic methodology, this approach correlates with the concept of "the principle of interconnected teaching of types of speech activity" [18]. Such an approach to learning is opposed to learning to be consistent (hearing - speaking - reading - writing), whose supporters are representatives of direct methods and verbal advancing in work. However, supporters of an integrative approach do not exclude the recognition of the priority of oral perception of educational material before writing. At the same time, the place of each type of speech activity in the learning system is determined by the purpose of the lesson and depends on the learning stage, since different types of speech activity in the classroom can act as both goals and means of learning [19, p. 13].

The methodological components of modular training include:

- course program;

- a training manual for students, containing practical material organized by topic, a description of examples (situations), questions for discussion;

- teacher's guide, detailed in accordance with the work program and chosen to work with the textbook;

- a collection of texts for additional reading.

In this regard, the design of courses, the development and implementation of domestic textbooks and teaching aids of the new generation specifically for students of non-linguistic universities are considered an indispensable condition for optimizing the process of teaching a foreign language to effectively form a foreign language professionally oriented competence. However, designing an English course for specific purposes is a complex process. The teacher is directly involved in it, since The goal of this course is to meet not only the needs of students of a particular field of study and profile, but also the requirements of the academic curriculum. Although at present the number of educational publications on an

There is hardly any language textbook for the sphere of professional activity in the market of printed products, which could be called ideal or meeting all needs arising in various situations and to solve all educational problems.

The concepts listed above have been reflected in the author's educational and methodological package, taking into account the national and regional component for students of geoecological specialties for the successful implementation of educational tasks [4, p. 280].

According to O. Lomakina, designing an English course for special purposes is a special kind of professional activity of a teacher in creating ideas about the educational process, which contributes not only to learning a foreign language, but also to educating and developing a student's personality [9, p. 224]. Design creates the basis for the processes that follow it - drawing up a work program, formulating goals, selecting content, defining principles, developing or choosing study materials, teaching students about the language itself and monitoring and evaluating its results.

Tasks solved in the process of implementing the task:

Designing an English course for specific purposes allows you to get answers to the following questions:

1. Why do students need to learn English?

2. Who will participate in the educational process? (This refers not only to students, but also to those who, to one degree or another, can influence the educational process, for example: teachers, school administration, the Ministry of Education and Science, etc.)

3. Where will the classes take place? What are the opportunities and conditions offered by the university? What are the limitations?

4. What are the training periods? What is the time otvoditsya? How is it distributed?

5. What should students learn? What is the language content of education and how is it presented? 6. What is the level of proficiency in the language being studied? What is the subject content of training (subject)?

7. What needs to be done for students to learn? What learning theory should be the basis of the course? What teaching method should be used? [9, p. 186] 
The above questions are interdependent and affect the design of the English language course for special purposes, and therefore, a foreign language should be considered not only from the standpoint of form, but also function, and learning how to use a foreign language is not reduced to syntax , and also includes other components of communication, namely:

- professionally oriented;

- subject-scientific;

- multicultural;

- social.

This is due to the following points: first, the modern specialist must be truly competent in the professional-oriented field of communication; secondly, the subject-scientific sphere of communication is an integral part of learning a foreign language. Professional competence should be viewed as readiness and ability to act appropriately in accordance with the requirements of the case, methodically and independently solve tasks and problems, and also self-assess the results of their activities, which cannot be done without knowledge of foreign languages [12, p. 9]. The urgent need for knowledge of foreign languages is dictated by the intensification of the process of world globalization. In the modern world, the image of a successful specialist, a professional in his business, is undoubtedly associated with the knowledge of several foreign languages. Knowledge means a foreign language not at the elementary level of communication, but at the professional level [1, p. 19]. Realization of this goal in a multicultural context in a non-language faculty is possible, firstly, with a good level of school curriculum, that is, if first-year students already have a basic set of knowledge and, secondly, if the educational process of the formation of a multicultural, professional personality will be carried out taking into account the integrative an approach to teaching a foreign language based on the principle of interconnected teaching of types of speech activity and interaction, and the interrelation of the problem of "language and culture" [2, p. 14].

\section{Literature:}

1. Андрющенок Е. В., Поцепай С. Н. Современные тенденции в обучении иностранным языкам и межкультурной коммуникации. Материалы международной заочной научно-практической конференции. 24 марта 2011 года.

2. Балабас Н. Н. О некоторых особенностях эффективного преподавания профессионально ориентированного иностранного языка (на примере французского языка). Современные тенденции в обучении иностранным языкам и межкультурной коммуникачии. Материаль международной заочной научно-практической конференции. 24 марта 2011 года.

3. Блиева Ж. М. Психолого-Педагогические Условия Формирования Языковой Компетенции Студентов В Учебно-Воспитательном Процессе ВУЗА. Автореферат диссертации на соискание ученой степени кандидата пед. наук. Владикавказ, 2008.

4. Блиева Ж. M. English for Ecology and Land Management. Владикавказ. 2015.

5. Джуринский А. Н. Поликультурное воспитание: сущность и перспективы развития. Педагогика. 2002. № 10

6. Жетписбаева Б.А. Теоретико-методологические основы полиязычного образования: автореф. дис.... докт. пед. наук : 13.00 .01$. M., $2010.46 \mathrm{c}$.

7. Караулов Ю. Н. Русский язык и языковая личность. М.: Наука, 1987. 264 с.

8. Лезина В. В. Развитие поликультурного образования в Республике Казахстан. Современные наукоемкие технологии. 2008. № 3. Сыродеева А. А. Поликультурное образование. М., 2004.192 с.

9. Ломакина О. Е. Технологические основы проектирования методической системы обучения иностранным языкам: концепция, теория, практика. Волгоград: Перемена, 2002.

10. Мигненко М. А. Языковая личность в пространстве культуры. Современная лингвистика: теория и практика. Мат-лы 7-й Межвуз. научно-методич. конф. Ч. 1. Краснодар: КВВАУЛ, 2007.

11. Мурзалинова А. Ж. Методические основы формирования функциональной грамотности учащихся-казахов при обучении русскому языку в 10-11 классах школы нового типа. Алматы, 2002.

12. Поляков О. Г. Английский язык для специальных целей: теория и практика: учеб. пособие. М.: НВИ Тезаурус, 2003.

13. Проект концепции развития системы образования Республики Казахстан до 2015 года. Астана, 2004.

14. Brown, H. Douglas. 2000. Principles of language learning and teaching. NY: Longman.

15. Jackson, H., \& Amvela, E. (2000). Words, meaning, and vocabulary: an introduction to modern English lexicology. London; New York: Cassell. Open linguistics series

16. Daller, H., Milton, J., \& Treffers-Daller, J. (2007). Modelling and assessing vocabulary knowledge. Cambridge: Cambridge University Press

17. Ting Toomey, Stella. 1999. Communicating across cultures. Guilford Publications

18. dic.academic.ru/dic.nsf/dic_synonims/283179

19. Взаимосвязанное обучение видам речевой деятельности. methodological_terms.academic.ru/. 